This article was downloaded by: [Krishna, Vadlamannati]

On: 23 June 2009

Access details: Access Details: [subscription number 912388773]

Publisher Routledge

Informa Ltd Registered in England and Wales Registered Number: 1072954 Registered office: Mortimer House, 37-41 Mortimer Street, London W1T 3JH, UK

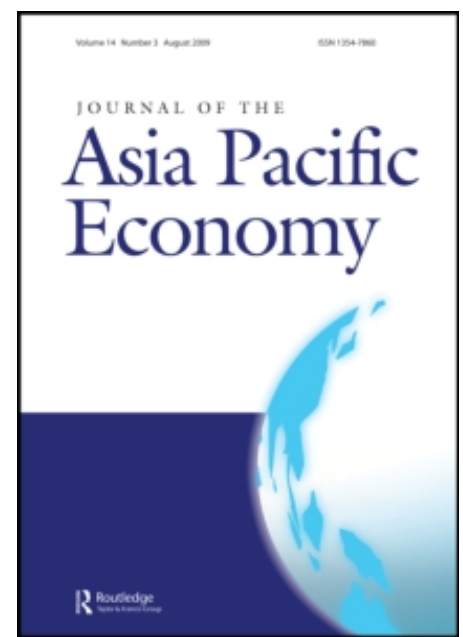

Journal of the Asia Pacific Economy

Publication details, including instructions for authors and subscription information:

http://www.informaworld.com/smpp/title content=t713703356

\title{
Determinants of foreign direct investment and volatility in South East Asian economies
}

Krishna Chaitanya Vadlamannati a; Artur Tamazian ${ }^{\text {b; }}$ Lokanandha Reddy Irala ${ }^{c}$

a Department of Applied Economics, Faculty of Business \& Economics, University of Santiago de

Compostela, Spain ${ }^{\mathrm{b}}$ Department of Finance and Accounting, University of Santiago de Compostela, Spain ${ }^{\mathrm{C}}$

Finance Area, ICFAI Business School, Hyderabad, Andhra Pradesh, India

Online Publication Date: 01 August 2009

To cite this Article Vadlamannati, Krishna Chaitanya, Tamazian, Artur and Irala, Lokanandha Reddy(2009)'Determinants of foreign direct investment and volatility in South East Asian economies',Journal of the Asia Pacific Economy, 14:3,246 — 261

To link to this Article: DOI: $10.1080 / 13547860902975010$

URL: http://dx.doi.org/10.1080/13547860902975010

\section{PLEASE SCROLL DOWN FOR ARTICLE}

Full terms and conditions of use: http://www.informaworld.com/terms-and-conditions-of-access.pdf

This article may be used for research, teaching and private study purposes. Any substantial or systematic reproduction, re-distribution, re-selling, loan or sub-licensing, systematic supply or distribution in any form to anyone is expressly forbidden.

The publisher does not give any warranty express or implied or make any representation that the contents will be complete or accurate or up to date. The accuracy of any instructions, formulae and drug doses should be independently verified with primary sources. The publisher shall not be liable for any loss, actions, claims, proceedings, demand or costs or damages whatsoever or howsoever caused arising directly or indirectly in connection with or arising out of the use of this material. 


\title{
Determinants of foreign direct investment and volatility in South East Asian economies
}

\author{
Krishna Chaitanya Vadlamannati ${ }^{\mathrm{a} *}$, Artur Tamazian ${ }^{\mathrm{b}}$ and Lokanandha Reddy Irala ${ }^{\mathrm{c}}$ \\ ${ }^{a}$ Department of Applied Economics, Faculty of Business \& Economics, University of Santiago de \\ Compostela, P.O. Box 15782, Spain; ${ }^{b}$ Department of Finance and Accounting, University of \\ Santiago de Compostela, P.O. Box 15782, Spain; ${ }^{\circ}$ Finance Area, ICFAI Business School, \\ Hyderabad, Andhra Pradesh 501203, India
}

\begin{abstract}
The objective of this paper is to identify and examine the determinants of barriers to foreign direct investment (FDI) in South East Asian economies. Based on our theoretical groundings, we identify potential barriers under four categories, namely macroeconomic policy factors, political factors, institutional factors and socioeconomic factors. Using cross-sectional time-series data for 17 South East Asian economies from 1996 to 2005, we test these set of barriers against per capita FDI inflows and volatility in FDI inflows using fixed effects pooled regression analysis. In the process, we also check as to how fragile our results are to the small but important changes, which we bring in the conditioning information set using robustness check. Our empirical evidence suggests that all the possible set of barriers identified have significant negative effect on per capita FDI and positive impact on volatility in FDI inflows. We therefore suggest that there is an urgent need to find the solutions to break these barriers that are acting as stumbling blocks in attracting FDI of their actual potential.
\end{abstract}

Keywords: FDI; barriers; South East Asia

JEL classifications: F21, O5

\section{Introduction}

The 2007 Asian Development Outlook released by the Asian Development Bank pegs the growth rate of Asia at $8.2 \%$ for 2008 . The rapid growth in Asia is led by two giants, one from South Asia and the other from East Asia, viz. India and China. The rate of growth of South Asia for 2007 was 8.1\%, slightly lower from 8.7\% in 2006, while East Asia's growth rate was $8 \%$ for 2007 , improving from $7.6 \%$ in 2006 .

A crucial problem for developing countries is that domestically generated resources are not sufficient to satisfy the growing needs of investments in education, infrastructure, exploitation of natural resources, etc. This is due to their inability to generate internal savings in accordance with their investment needs. One of the generally cited reasons for the growth in Asia is foreign direct investment (FDI). Also, FDI is one of the most effective ways by which developing economies become integrated to the global economy as it provides not only capital but also technology and management know-how necessary for restructuring firms in the host economies.

${ }^{*}$ Corresponding author. Email: kcv.dcm@gmail.com 
A large chunk of FDI in Asia is attracted by East and South East Asia led by China and other five major economies, namely Thailand, Malaysia, Indonesia, South Korea, Vietnam and Philippines. Interestingly, the 1997 South East Asian economic crisis did not seem to have drastically affected the FDI inflows of South East Asian economies. A report released by the Asian Development Bank in 2001 said,

the crisis has not introduced a major discontinuity in FDI in the affected countries, apart from a modest decline in inflows in the immediate aftermath of the crisis. The FDI inflows to the five countries - Indonesia, Republic of Korea, Malaysia, Philippines, and Thailand - collectively reached US\$19.2 billion immediately before the crisis, in 1996. They dipped to 16.7 US\$ billion in 1998, but rebounded to 17.4 US\$ billion the following year.

Contrary to everybody's expectations that 'after the crisis, there would be a rollback of various liberalization polices related to attracting FDI', all the countries affected by the crisis had engaged in further liberalizing the regulations related to attracting FDI and this kept driving the FDI inflows in this region. By 2006, the total FDI inflows of South East Asian economies excluding Japan stood at US\$155 billion (UNCTAD 2007).

On the other hand, the South Asian region ${ }^{1}$ led by India lags much behind East Asia in attracting FDI. South Asia as a region in 2006 attracted FDI worth US\$20 billion. Though this is a great improvement from just under US\$3 billion in 2000 (Bhuhyan 2003), it is far behind its South East Asian counterparts.

However, all the South Asian economies are consistently implementing the economic reform policies that are aimed at integrating their economies with that of the world economy. Sahoo (2006) noted that there is a sea change in the attitude of South Asian economies in attracting FDI and there is a huge positive affect of increased FDI inflows on the economic growth in all these countries. ${ }^{2}$

Though South Asia has enormous potential to attract FDI, many believe that there are various political and institutional problems that are acting as hindrances. Excluding India, all the South Asian economies are experiencing political turmoils in one form or the other. Also, the institutional structures are very weak, creating a wide gap between the policies and their implementations. Added to this, widespread corruption and poor social and physical infrastructure facilities are believed to be acting as major investment hurdles in these economies. Against this backdrop, it would be very interesting to explore the determinants of FDI inflows in South Asian and South East Asian economies. This paper makes an attempt through the examination of 17 important South and East Asian economies which are experiencing a rapid surge in FDI inflows. The breadth of issues considered include socioeconomic, labour-related, policy and institutional matters. While Section 1 is the curtain raiser, Section 2 reviews relevant literature. Section 3 explains the research design, followed by the results and estimates in Section 4. Finally, Section 5 summarizes the study.

\section{Related literature}

Several empirical studies tried to clarify which are the determinants of FDI in order to achieve higher rates of economic growth and welfare in the host country. In this context, Wheeler and Mody (1992) examine American firms investing abroad and mention that political risk factors, the functioning of bureaucracy, corruption and judicial system have strong impact on these firms. A study done by the World Bank shows that the quality of institutions affects the firms' behaviours. Using a time-series analysis, Jun and Singh (1996) found that when political risk is high, FDI is affected negatively. Gastanga et al. (1998) 
examined the relationship between political variables and found that high enforcement mechanisms and low corruption levels affect FDI positively. Noorbakhsh et al. (2001) empirically tested the hypothesis that the level of human capital in host countries may affect the geographical distribution of FDI. These empirical findings are: (1) human capital is a statistically significant determinant of FDI inflows; (2) human capital is one of the most important determinants; and (3) its importance has become increasingly greater through time. Pournarakis and Varsakelis (2002) analyzed that institutional factors such as civil and political rights and corruption were critical in explaining the behaviour of FDI inflows in the transition economies during the 1990s. They used a panel data set for 10 countries of the Central and Eastern Europe region for the period 1997-2000. They found that the weak civil and political rights status in many countries of the region prevents them from becoming attractive locations for FDI. A transparent business environment in these countries is a prerequisite to attract FDI from the members of the EU and the US primarily in low-tech sectors. Tondel's results (2001) proved that FDI inflows are driven by the transition progress (the transition index being the only significant variable). The author claimed that higher risk sensitivity suggests 'a role for the efficiency seeking or vertical investments'. Bevan and Estrin (2000) provided evidence that the private sector share of gross domestic product (GDP) is of high significance and hence suggested that this is a 'key factor in determining perceived country risk'.

Kinoshita and Campos (2003) examined the factors accounting for the geographical patterns of FDI inflows among 25 transition economies by utilizing panel data between 1990 and 1998. They classified the location determinants into three categories:

(1) The country-specific advantages such as low-cost labour, large domestic market, skilled labour force, adequate infrastructure and proximity to the Western European markets.

(2) Institutions, macroeconomic policy and other policies that facilitate businessoperating conditions.

(3) The persistent pattern of FDI driven by agglomeration economies.

Using the fixed effects and GMM models, they related per capita FDI stock as a function of these three broad categories of variables. Their main finding is that the most important determinants of FDI location are institutions and agglomeration economies that override the importance of other economic variables. They also found that the region's FDI is motivated by the abundance of natural resources and labour cost. Poor quality of the bureaucracy is found to be a deterrent to foreign investors as they conceive it as a high transaction cost which directly affects profitability of their investment projects. A similar argument is made with respect to the rule of law, which was also found to be an important determinant of FDI in transition economies. Furthermore, foreign investors prefer transition countries that are more open to trade and with fewer restrictions on FDI as the destinations of their investment. They also found that progress on economic reform (external liberalization) plays a large role. Finally, institutions, agglomeration, abundance of natural resources and infrastructure are crucial factors for FDI.

\section{Research design}

\subsection{Regression models}

We propose two baseline regression models: one to capture the determinants of FDI, and the other to capture the determinants of its volatility. Each baseline model is backed by four more models with a different mix of independent variables. 


\subsubsection{Modelling for determinants of FDI inflows}

The typical dependent variable used in literature is usually the level of FDI inflows in real value. To control for linear trend, some prefer FDI as a percentage of GDP. We feel that FDI inflows or FDI/GDP is a better indicator for a single country time series, but not for our study because it does not control for the size of a country. Therefore, to control for the size of a country, we divide the total volume of FDI inflows of each country by their population size. Thus, our dependent variable for the first model is per capita FDI inflows in US\$.

\subsubsection{Modelling for determinants of volatility in FDI inflows}

In the second model dealing with volatility in FDI inflows, we make use of five-year standard deviations of actual FDI inflows to arrive at volatility figures. The volatility in FDI inflows is computed as below:

$$
\mathrm{FDI}(\mathrm{Vol})=\frac{\sigma_{i, t-1}^{\mathrm{FDI}}+\sigma_{i, t-2}^{\mathrm{FDI}}+\sigma_{i, t-3}^{\mathrm{FDI}}+\sigma_{i, t-4}^{\mathrm{FDI}}+\sigma_{i, t-5}^{\mathrm{FDI}}}{(\text { Actual inflows })_{i t}}
$$

\subsection{Independent variables}

\subsubsection{Macroeconomic factors}

Labour. To measure the impact of labour-related issues, we have considered unionized labour and the number of strikes and lockouts. We believe that higher the membership of the union, the stronger the labour union would be. Thus, a bigger labour union is detrimental to the quality of FDI. Therefore, we expect negative signs for both the variables against FDI inflows and positive signs against volatility in FDI inflows.

Policy. Focusing on the set of policy variables, we introduce capital account convertibility dummy, which takes into account the value ' 0 ' for the years in which there was no convertibility on capital account, and ' 1 ' otherwise. Therefore, we expect a positive association between capital account covertability and FDI inflows. We also capture the effects of economic crisis for all the East Asian economies and take the value of ' 1 ' for the years of crisis from 1996 to 1998 and '0' for rest of the years. However, we do code the same for India, Sri Lanka, Pakistan and Bangladesh. Since economic crisis is detrimental to attracting FDI, we expect a negative sign for this variable.

Potential macroeconomic risk. To control major potential economic risk, we capture the potential macroeconomic risk based on a comprehensive risk index that includes key monetary, fiscal, external and structural risk indicators. This includes the size of the current account deficit and fiscal deficit, inflation rate, unemployment rate, exchange rate instability and average lending rates. A country's overall score is arrived from multiplying the weights assigned to each variable ${ }^{3}$ with the value of the indicator. Thus, it is a simple weighted average index and arguably a crude way of gauging the potential economic risk. Having said that, this index provides some idea on movement of macroeconomic risk factors, which is a sign of economy heading towards potential macroeconomic risk. For example, Thailand, Indonesia and Korea experienced negative value in the index between the period 1996 and 1998, suggesting that the potential risk was high. Thus, the higher the potential risk index, the lower the FDI inflow. 


\subsubsection{Institutional factors}

Track record of government. Following the method of Joseph et al. (2007), we capture the track record of the governments as an important policy barrier. The poor track record of a government acts as a disincentive to attract FDI. To capture the track record of a government, we use simple standard deviation of per capita GDP growth rate for the past five years. Higher values would mean higher volatility and poor track record of the government. We believe that higher values are an indicator towards unstable economic growth, which is a resultant of past government policies and its impact on quality of FDI is bound to be negative. Arguably, it is a crude way of gauging the track record of the government; we believe that economic development (proxied by per capita GDP growth rate) best measures the standard of living, which in turn is a resultant of economic policies adopted by the government. We adopted the per capita GDP growth rates for the countries from the Asian Development Bank's 2006 macroeconomic indicators.

Corruption. We also take into account the perceived values of corruption, an important bureaucratic barrier. We consider the Transparency International's (2007) corruption perception index (CPI), which shows whether the country is making an improvement in the controlling for corruption. The ratings are given on a scale of $0-10$, wherein 0 is no control in corruption levels and 10 is maximum control over corruption levels. There are conflicting views about the impact of corruption on FDI. While some argue that increase in corruption levels is highly associated with rapid growth in FDI inflows (Robertson and Watson 2004, Egger and Winner 2005), other argue that corruption leads to and creates operational inefficiencies, and hence is detrimental in attracting FDI (Habib and Leon 2006). Due to the conflicting findings in the literature, we make no assumptions about the relationship and direction between corruption levels and FDI.

Civil liberties. Going by the common conjecture that civil repression boosts FDI in developing countries, we included the civil liberties index as an important institutional barrier variable. We believe that foreign investors attach importance to civil liberties as it includes issues not only related to the state like rule of law, but also related directly to the freedom of business. Freedom of business and cooperation is one of the key components of civil liberties. Therefore, we expect a positive association between civil liberties and attracting FDI. We adopt the civil liberties index from Freedom House which measures this on the scale of 1-7, where 1 means higher civil liberties and 7 otherwise.

\subsubsection{Political factors}

Political regime and political instability. The effect of political regime in attracting FDI is the most contentious topic in political economy literature. The study by Fatehi and Safizadeh (1989) shows that MNCs give utmost importance to the political stability factor while deciding to invest in a project. Conventional wisdom posits that autocracies are better off than democratic set-up in implementing neoliberal policies of their choice and hence can attract FDI. Often the case studies of India and China are cited as apt examples. There are in fact studies by Haggard and Kaufman (1992) and Weyland (1998) which show that policy choices of the interest to the government can be easily implemented in authoritarian rule as the state is often insensitive towards general public sentiments and opinions. Also, the authoritative regimes are not under constant pressure to seek public opinion. On the other hand, it is believed that the implementation of such reform policies, which are key in attracting FDI, is very slow in democratic regimes. This is because it has various compulsions like facing public anger against a policy decision, coalition 
compulsions, differences within the ruling party alliances and so on. However, there are also studies (Przeworski et al. 2000, Biglaiser and Danis 2002, Jakobsen and De Soysa 2006) which show that it is the democratic countries that better protect the property rights and are efficient in distributing the resources accordingly, thus giving scope for attracting higher levels of FDI inflows.

Due to the conflicting arguments in the literature, we make no assumptions about the relationship and direction between political regime and FDI. To measure political regime, we include regime-type data Polity IV constructed by Marshall and Jaggers (2002). We then follow Londregan and Poole (1996) by subtracting Polity IV's autocracy score from its democracy score, giving rise to the final democracy score that ranges from +10 to -10 , wherein +10 is the most democratic, +5 partially democratic and -10 fully autocratic.

Conflicts. Empirical studies have found significant negative impact of conflict on short-term economic growth and development (Collier 1998). Conflicts affect the growth and development process in many ways. It leads to diversion of productive resources for unproductive purposes where the returns on such investments are but nil (Grossman and Kim 1996). In an already crippled state, conflicts increase the military spending, which in turn crowds out foreign investments creating huge negative fiscal impact and hampers the prospects of socioeconomic development (Deger and Sen 1983, Klein 2004, Vadlamannati 2008). With lower economic growth and development, and higher amounts of government consumption, it becomes very difficult for the governments to attract FDI. The findings of Vadlamannati and Tamazian (2006) with respect to Sri Lanka show that internal state conflict affects FDI attractiveness and actual inflows. Extending this study further, Vadlamannati (2007) finds that internal conflict not only affects the FDI attractiveness and inflows, but also deters the quality and growth rate and increases the volatility. Thus, we expect a negative association between conflicts and FDI. We introduced conflict variables as dummy coded 1 if there was conflict either internal or external in the country in that year and 0 otherwise. The data for this variable is from the 2007 Uppsala updated data set on conflicts.

\subsubsection{Socioeconomic factors}

Literacy and infant deaths. We are also interested to see if poor socioeconomic conditions of the state can act as potential barriers in attracting FDI. To capture this affect, we introduce two variables which best represent the socioeconomic conditions, viz. literacy rate and infant mortality rate. Initially, we thought to include inequality and poverty rates as proxies for poor socioeconomic conditions. However, due to lack of time-series data of the same for 17 South East Asian economies forced us to use the above as proxies. The literature shows strong support for the conjecture that redistributive social welfare state policies are valued by multinationals, because they signal a government's commitment to social stability (Görg et al. 2007). Going by the literature, we feel that it is very important to see whether the poor socioeconomic conditions in these emerging economies hinder attracting FDI; i.e. are FDI inflows sensitive towards poor socioeconomics conditions in developing countries? The data for both the variables were adapted from the statistical yearbooks of the countries published by the PSR group.

\subsection{Sample and data}

The annual data for FDI inflows comes from the database of the United Nations Commission for Trade and Development (UNCTAD). The population data was taken from World Bank's 
World Development Indicators (2006) to arrive at per capita FDI inflows. We also depended on the same source to trace back the past five years of FDI inflows to compute volatility.

Similarly, we have identified a specific set of independent variables which are common across the models. We have also used some control variables in all the models. The general model may be specified as below:

$$
\mathrm{FDI}=\zeta+\sum_{i=1}^{17} \psi_{1} X_{i t}+\sum_{i=1}^{17} \psi_{2} Y_{i t}+\varepsilon
$$

where $X$ is the vector of key independent variables and $Y$ the vector of control variables; $\psi_{1}$ and $\psi_{2}$ are the corresponding coefficient vectors.

This empirical analysis covers about 17 countries (five South Asian, five East Asian and seven Pacific-rim regional countries) for the period 1996-2005. These countries vary in size, political climate and the levels of socioeconomic developmental aspects. These and other fixed or time-varying country attributes like administrative and bureaucratic hurdles are directly correlated with the quality of FDI, leading to omitted variable bias in our models. Therefore, following Beck and Katz (1996), the fixed effects method is performed in suspicion that there are other factors than those captured in our explanatory variables affecting the economic reforms process and its speed. The pooled time-series cross-sectional (TCSC) data may exhibit heteroskedasticity and serial correlation problems. These problems do not bias the estimated coefficients, as pooled regression analysis in itself is a more robust method for large sample consisting of cross-sectional and time-series data. However, they often tend to cause biased standard errors for coefficients, producing invalid statistical inferences. To deal with these problems, we estimated for all the models the Huber-White robust standard errors clustered over countries. These estimated standard errors are robust to both heteroskedasticity and a general type of serial correlation within the cross-sectional unit (Rogers 1993, Williams 2000).

Based on our arguments earlier, we should expect negative signs for the large number of the independent variables (see Table 1). However, there are some coefficients whose signs cannot be expected precisely because of the conflicted findings in the literature. Therefore, it is not possible to accurately expect the signs of them.

\section{Empirical results and estimates}

In this section, we present the regression results. Table 2 captures the regression estimates for per capita FDI inflows. The estimates of the regression results for volatility in FDI inflows are presented in Table 3. Important statistics are presented at the end of each table. All the results include white heteroskedasticity-consistent standard errors and covariance to counter the problem of heteroskedasticity.

\subsection{FDI inflows}

In model 1, we find that both labour-related variables (unionized labour and number of strikes and lockouts) have a significant negative impact on per capita FDI inflows. The coefficient values of both show that the effect of the former is higher on per capita FDI inflows. Though unionized labour by itself does not mean strong representation of workers' interests, it reflects the strength of labour union. This is supported by the increasing number of strikes and lockouts in which the role of labour unions is key. The results of the potential 
Table 1. Summary of theoretical explanations.

\begin{tabular}{lcc}
\hline Determinants & $\begin{array}{c}\text { Hypothesized effect on per } \\
\text { capita FDI inflows }\end{array}$ & $\begin{array}{c}\text { Hypothesized effect on } \\
\text { volatility in FDI }\end{array}$ \\
\hline Economic and policy variables & Negative & Positive \\
PMERI & Negative & Positive \\
Unionized labour & Negative & Positive \\
Strikes \& lockouts & Positive & Negative \\
Capital account convertibility & Negative & Positive \\
Economic crisis & Positive/Negative & Positive/Negative \\
Political factors & Negative & Positive \\
Political regime & Negative & Positive \\
Political instability & Positive/Negative & Positive/Negative \\
Conflicts & Positive/Negative & Positive/Negative \\
Institutional factors & Negative & Positive \\
Track record of the government & & Positive \\
Levels of corruption & Negative & Positive \\
Civil liberties & Negative & \\
Socioeconomic factors & & \\
Literacy rate & & \\
Infant deaths & &
\end{tabular}

macro economic risk index (PMERI) could not find any statistical significance on per capita FDI inflows. A higher value of PMERI suggests the economy being on a safer side. These results are consistent with the results obtained for the track record of a government. The positive effect of the track record of a government nullifies the fact that there is a danger of potential macroeconomic risk. We find that capital account convertibility is positively correlated with per capita FDI inflows. This is statistically significant at $1 \%$ level. But we find significant (at 5\% level) negative impact of economic crisis on per capita FDI inflows.

With respect to political factors, consistent with the findings of Huntigton and Dominguez (1975), Greider (1998), O’Donnell (1988), Li and Resnick (2003) and Guerin and Manzocchib (2007), we find that increase in Polity IV scores leads to a decline in per capita FDI inflows. This negative impact is largely due to the curtailment of workers' rights and cutting down of the union representation. The other reason is that in our sample of 17 countries, we find that four countries are extremely autocratic ${ }^{4}$ and as many as five countries are partially democratic. ${ }^{5}$ The partial democracy (which is neither fully democratic nor fully autocratic) actually acts as a disincentive for foreign investors because the decision-making process is slow, institutions are weak and they face higher threats of political instability. These arguments are supported by the findings of Hegre et al. (2001). We also find a negative impact of political instability on per capita FDI inflows. Though the coefficient is very strong, the relationship is quite weak with a $15 \%$ confidence level. As majority of the countries in our sample are partial democracies, the scope for political instability is higher. This acts as a major disincentive in attracting FDI as it leads to an increase in the probability of changes in major economic policies by the new government. The results of the conflict variable strangely have a $1 \%$ significant positive association with per capita FDI inflows. The one obvious reason is that there are no major conflicts, either external or internal, in this region, barring Sri Lanka and minor conflicts in India, Indonesia and Philippines. During the whole sample period there was only one external conflict, between India and Pakistan in 1999 at Kargil. 


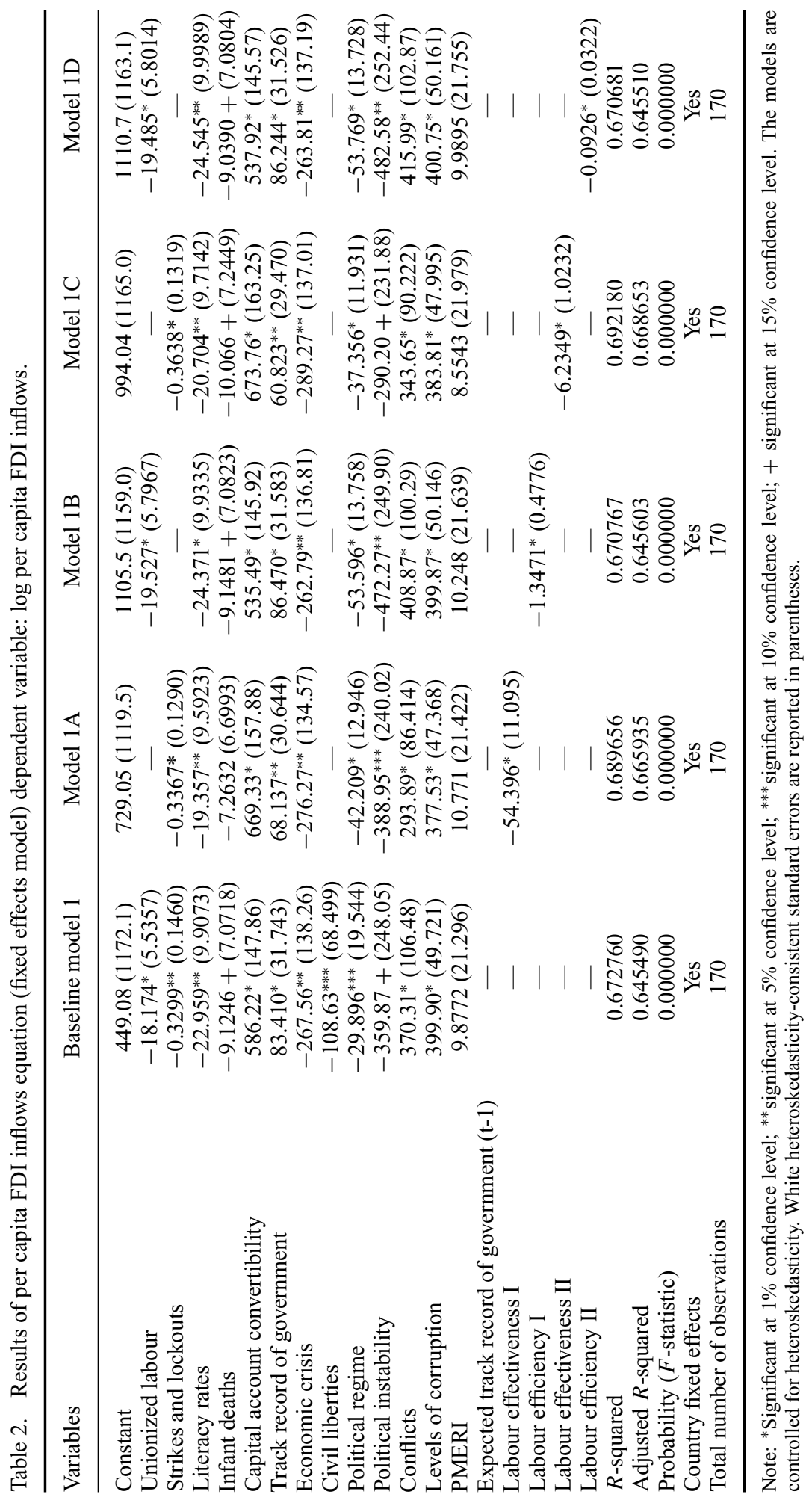




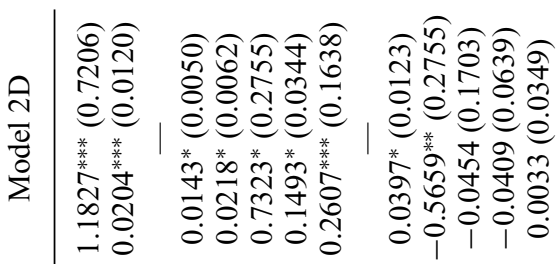

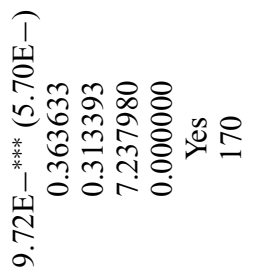

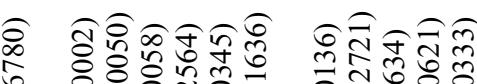

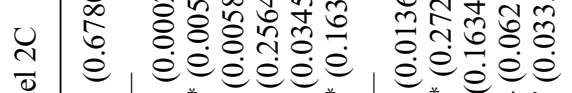

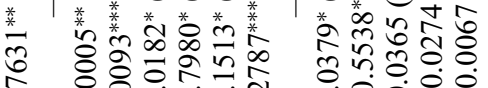

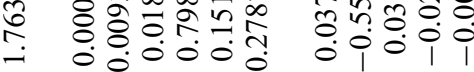

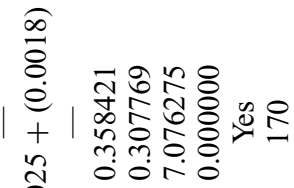

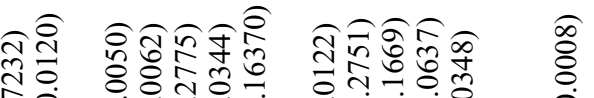

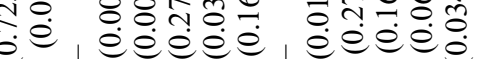

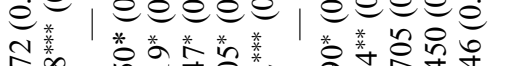

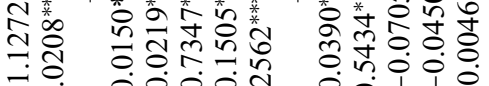

1

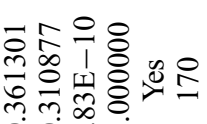

$\bar{\Xi}$

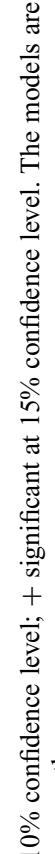

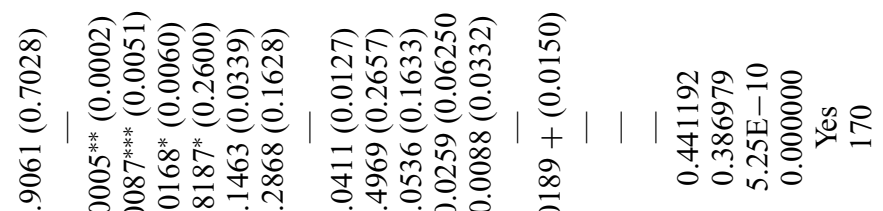

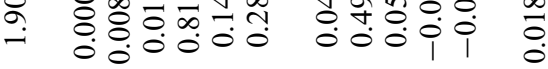

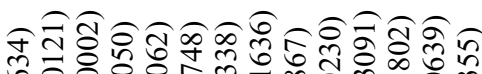

过e

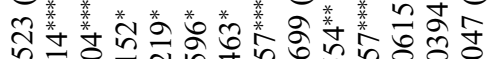

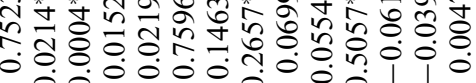

ํํำ

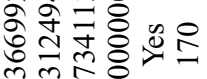

?००० 
The results of institutional factors like the corruption level, which is very high in these regions, are found to encourage FDI inflows. We find 1\% significant positive association of perceived corruption levels with per capita FDI inflows. One reason for this is that the foreign firms are engaged in lobbying to get the things done and end up involved in corruption largely at the bureaucratic level (Robertson and Watson 2004). The track record of the government largely depends on the government polices, which is reflected in terms of economic policies initiated; it shows a $1 \%$ significant positive effect on per capita FDI inflows. But the most interesting findings of institutional factors are related to civil liberties. We find that its impact on per capita FDI inflows is negative with a statistical significance of $10 \%$. But the interesting observation is the comparison between the results of civil liberties and political regime. We find that though both are statistically significant at $10 \%$ confidence level, the coefficient of civil liberties is twice the political regime. This also means that although foreign investors consider both political regime and civil liberties as important determinants, they give higher preference to civil liberties. This is because civil liberties include 'freedom to business firms'. Thus, foreign investors are attracted by those regimes which give higher importance to freedom of business followed by other political factors like regime and regime change.

Finally, with respect to socioeconomic factors, both literacy and infant mortality rates show negative impact on per capita FDI inflows. The negative effect of literacy rates on FDI is because majority of the countries in the region suffer from lower literacy rates. In the case of the number of infant deaths, excluding Japan, Hong Kong, Taiwan and Singapore, the number is quite high in rest of the countries.

We bring back the debate on the unionized labour and its degree of membership and representation. Earlier we argued that union membership and strikes and lockouts are negatively associated with per capita FDI inflows. However, our sample includes countries which are fully autocratic: China, Hong Kong, Burma and Vietnam. In autocratic countries labour unions control workers to enforce the government's decisions (Harms and Ursprung 2004). To account for this factor, we introduce four new variables in interaction terms ${ }^{6}$ which include (1) effective labour union I and II and (2) efficiency of labour union I and II:

$$
\text { Effective labour union }(\mathrm{I})=\frac{\text { Unionized labour }}{\text { Civil liberties }}
$$

This ratio helps understand how effective the labour unions are in all the three types of regimes, viz. fully democratic, fully autocratic and partially democratic. One of the other important components of civil liberties is the existence of free trade unions. We now follow a similar method to test for labour union efficiency:

$$
\text { Labour union efficiency }(\mathrm{I})=\frac{\text { No. of strikes \& lockouts }}{\text { Civil liberties }} \text {. }
$$

We take this into account because the higher the existence of freedom for trade unions, the greater the chances for strikes and lockouts, which in turn is a measure for the other side of unionized labour. Apart from this, we also include other variables that act as proxy for labour effectiveness and efficiency:

Effective labour union (II) $=$ Unionized labour $\times\{8-$ Civil liberties index $\}$,

Labour union efficiency (II) $=$ No. of strikes $\&$ lockouts

$$
\times\{8-\text { Civil liberties index }\} \text {. }
$$


We introduce these four variables separately in models $1 \mathrm{~A}, 1 \mathrm{~B}, 1 \mathrm{C}$ and $1 \mathrm{D}$. We find that in all the models, these variables show a significant negative sign. In model $1 \mathrm{~A}$ we find that labour effectiveness I has 1\% significant negative impact on per capita FDI inflows. The point that is noteworthy is that the coefficient value is much higher, almost double the 'original labour unionized' variable in model 1 (see Table 2). This suggests that higher effectiveness of the labour unionism acts as the disincentive to attract FDI. Same is the case with respect to model $1 \mathrm{~B}$ in which we introduce efficiency of labour union I. The results show $1 \%$ significant negative association with per capita FDI inflows. Even here, we find the coefficient value to be higher than the 'original strikes and lockout' variable in model 1 (see Table 2). This also suggests that the efficiency of labour unionism is a very strong deterring factor of per capita FDI inflows. To cross-check these results, we once again test for labour effectiveness and efficiency, but taking civil liberties into account. We still find that both labour effectiveness II and labour efficiency II share 1\% significant negative impact on per capita FDI inflows. This highlights that liberal labour workforce is indeed not helpful in attracting FDI inflows.

\subsection{Volatility of FDI inflows}

In Table 3 we present the results of volatility of actual FDI inflows. The most interesting finding is that all the variables which were negatively associated in our earlier model on per capita FDI inflows have now turned positive. This means that an increase in these independent variables leads to higher volatility in FDI inflows. We find that both unionized labour and strikes and lockouts are $10 \%$ significant and positively associated with volatility in inflows. This suggests that aggravation in labour union leading to strikes and lockouts might lead to uncertainty in terms of attracting FDI inflows. We find that PMERI has no statistical significance towards volatility in FDI inflows. This confirms the consistency in results obtained in the previous model. This also suggests that there is no great potential macroeconomic risk which can actually threaten the decline of FDI. We also find that economic crisis is associated with increase in volatility in FDI inflows. We saw the negative portfolio investments and sudden withdrawal of investments by foreign investors during the East Asian crisis leading to an increase in volatility in FDI numbers. The results of policy variables are mixed. We find that capital account convertibility efforts have still a long way to go to reduce the volatility in FDI inflows. However, we could see that this relationship is strong, suggesting that indeed more steps are necessary to liberalize the capital account convertibility.

With respect to political factors, the results are largely in line with our previous findings. Both political regime and political instability share positive effect on volatility in FDI inflows and are statistically significant at $1 \%$ and $10 \%$ confidence levels, respectively. The coefficient values of both show that the latter has a more drastic impact on volatility than the former. Thus, investors attach greater importance to instability of the government to regime. This is because change in the ruling party of the government can lead to a change in economic policies, which may or may not be on the expected lines of foreign investors.

The results of institutional variables suggest that neither civil liberties nor conflict nor perceived levels of corruption are having any significant impact, though they carry appropriate expected signs. Strangely, we find that the track record of a government is leading to volatility in FDI inflows and is significant at the $1 \%$ confidence level. This also suggests that there is a scope to improve the track record of a government, which can help bring down volatility in economic growth to stabilize the FDI inflows. Lastly, the socioeconomic variables show $1 \%$ significant positive relationship with volatility in 
inflows. Poor human capital arising out of vulnerable socioeconomic conditions might also lead to uncertainty in the inflows of FDI.

In models $2 \mathrm{~A}$ and $2 \mathrm{~B}$, we find that union effectiveness I and union efficiency I are positive, and are significant at the $15 \%$ confidence level. The coefficient values of both in comparison to the values presented in baseline model 2 have not increased drastically. This proves that although liberal unionized workforce helps deterring FDI inflows, it does not stand on the strong ground to argue that it leads to volatility in FDI inflows. We introduced union effectiveness and efficiency II in models 2C and 2D (see Table 3). We find both having positive signs, but union effectiveness II is statistically significant at the $15 \%$ confidence level, whereas union efficiency II is significant at $10 \%$.

\section{Summary and conclusion}

Although there are several studies related to determinants of FDI, concentration on Asian economies has been low. We offer a new set of arguments with a holistic approach to explore the determinants of per capita FDI inflows and level of volatility in actual FDI inflows. We considered the determinants under four heads, viz. economic and policy factors, socioeconomic factors, institutional factors and political factors. The empirical analysis covers 17 countries from 1996 to 2005.

Our findings in the baseline models show that poor socioeconomic conditions and labour-related issues are the major determinants. We further tested the effectiveness and efficiency of labour unionism by introducing two different sets of variables. The evidence further strengthened our earlier findings that indeed labour issues act as potential determinants. The labour reforms in countries like India, Sri Lanka and Pakistan are kept on hold due to political compulsions. We feel that labour regulation reforms have to be taken up by these countries in order to become more attractive investment destinations. We expected the PMERI to be largely negative in all the models, but it was found to be insignificant. The findings for institutional factors portray a mixed picture. But the results related to political factors highlight the importance of stable political system.

One of the limitations of our study is that we could not account for the administrative barriers - which the foreign investors often face in developing economies - due to the lack of an exact quantifiable variable that can precisely define the administrative and bureaucratic hurdles. Though we accounted for omitted variable bias using fixed effects model, this may reduce the bias but not completely eliminate the problem. Therefore, we advocate further research in investigating policy barriers to FDI by taking into consideration the various types of administrative, bureaucratic and regulatory barriers that play a key role in affecting the decision of a foreign investor to invest in a particular country.

\section{Acknowledgements}

We would like to thank the anonymous referee of the Journal of the Asia Pacific Economy and also the anonymous reviewer of WDI Michigan University for their comments and suggestions to improve earlier drafts of this article.

\section{Notes}

1. The South Asian region is defined to include Burma and exclude Nepal, Afghanistan, Bhutan and Maldives as we could not get the some important data for these countries.

2. This study excludes Burma, Bhutan and Maldives. The countries considered are India, Pakistan, Sri Lanka, Bangladesh and Nepal. 
3. We divided the total weight of 100 into seven equal parts and assigned each indicator a weight of 14.29 to be precise.

4. They include China, Burma, Vietnam and Hong Kong.

5. They include Sri Lanka, Singapore, Bangladesh, Indonesia and Malaysia. Though South Korea was under partial Democracy till 1997, it made the transition to full democracy from then on.

6. Two of those four interactive terms are proposed by Harms and Ursprung (2004) themselves. We use their own methodology to check for the arguments.

\section{References}

Asian Development Bank, 2001. Economic review report on South-East Asia. Manila, Philippines: Asian Development Bank.

Asiedu, E. and Lien, D., 2004. Capital controls and foreign direct investment. World development, 32 (3), 479-490.

Beck, N. and Jonathan, N.K., 1996. Nuisance vs. substance: specifying and estimating time-series cross-section models, Political analysis, 6, 1-36.

Bevan, A.A., Estrin, S., and Meyer, K., 2000. Institution building and the integration of Eastern Europe in international production. London: Centre for New and Emerging Markets, London Business School, Discussion Paper No. 11.

Bhuhyan, W., 2003. A foreign investor's experience with administrative barriers in South Asia. Keynote address for conference South Asia FDI roundtable, Maldives.

Biglaiser, G. and Danis, M., 2002. Privatization under democracy versus authoritarian rule. Comparative political studies, 25 (1), 83-102.

Collier, P., 1998. On the economic consequences of civil war. Oxford economic papers, 50 (4), 563-573.

Deger, S. and Sen, S., 1983. Military expenditure, spin-off and economic development. Journal of development economics, 13, 67-83.

Egger, P. and Winner, H., 2005. Evidence on corruption as an incentive for foreign direct investment. European journal of political economy, 21, 932-952.

Fatehi, K. and Safizadeh, M.H., 1989. The association between political instability and flow of FDI. Management international review, 29 (4), 4-13.

Gates, S., Gleditsch, N.P., and Hegre, H., 2001. Democracy and civil conflict after the cold war. In: D. Berg-Schlosser and R. Vetik, eds., Perspectives on democratic consolidation in Central and Eastern Europe. New York: Columbia University Press, for East European Monographs, 185-194.

Görg, H., Molana, H., and Montagna, C., 2007. FDI, tax competition and social expenditure. Working Paper, School of Social Sciences, University of Dundee, Scotland.

Greider, 1998. One world, ready or not, manic logic of capitalism. New York: Simon \& Schuster.

Grossman, H.I. and Kim, M., 1996. Predation and accumulation, Journal of economic growth, 1 (3), $333-350$.

Guerin, S.S. and Manzocchib, S., 2007. Political regime and vertical vs. horizontal FDI. Luiss Lab of European Economics, LLEE Working Document No. 49.

Habib, M. and Leon, Z., 2002. Corruption and FDI. Journal of international business studies, 33 (2), 291-307.

Haggard, S. and Kaufman, R., 1992. The politics of economic adjustment. Princeton, NJ: Princeton University Press.

Harms, P. and Ursprung, H.W., 2004. Do civil and political repression really boost FDI. Economic inquiry, 40 (4), 651-663.

Hegre, H. et al., 2001. Toward a democratic civil peace? Democracy, political change and civil war, 1816-1992. American political review, 95 (1), 33-48.

Huntington, S.P. and Dominguez, J.I., 1975. Political development. In: F.I. Greenstein and N.W. Polsby, eds. Handbook of political science. Reading, PA: Addison Wesley, 1-114.

Jakobsen, J. and De Soysa, I., 2006. Do foreign investors punish democracy? Theory and empirics, 1984-2001. Kyklos, 59 (3), 383-410.

Joseph, P.F. et al., 2007. Does 'good government' draw foreign capital? Explaining China's exceptional FDI inflow. WPS4206, World Bank. 
Jun, K.W. and Singh, H., 1996. The determinants of foreign direct investment: new empirical evidence, Transnational corporations, 5, 67-106.

Kinoshita, Y. and Campos, N.F., 2003. Why does FDI go where it goes? New evidence from the transition economies. IMF Working Papers No. 03/228, Washington, IMF, 1-34.

Klein, L., 2004. The peace dividend. Keynote lecture delivered at Ninth Annual Meeting of LACEA, San José, Costa Rica, November 5.

Li, Q. and Resnick, A., 2003. Reversal of fortunes: democracy, property rights and FDI inflows in developing countries. International organization, 57 (1), 1-37.

Londregan, J.B. and Poole, K.T., 1996. Does high income promote democracy? World politics, 49 (1), $1-30$.

Marshall, M.G. and Jaggers, K., 2002. Polity IV project: political regime characteristics and transitions, 1800-2000. College Park: University of Maryland.

Pournarakis, M. and Varsakelis, N.C., 2002. Foreign direct investment in Central and Eastern Euriopean Countries: do institutions matter? EIBA Annual conference, December 2002, Athens, Greece.

Przeworski, A. et al., 2000. Democracy and development. Political institutions and well-being in world, 1950-1990. Cambridge: Cambridge University Press.

Robertson, C.J. and Watson, A., 2004. Corruption and change: the impact of foreign direct investment. Strategic management journal, 25 (4), 385-396.

Rogers, W.H., 1993. Regression standard errors in clustered samples. Stata technical bulletin, 13, $19-23$.

Sahoo, P., 2006. FDI in South Asia: policy, trends, impact and determinants. ADB Institute Discussion Paper No. 56, ADB, Manila, Philippines.

Transparency International, Germany, 2007. Corruption perception index [online]. Available from: http://www.transparency.org/policy_research/surveys_indices/cpi.

UNCTAD, 2007. FDI statistics [online]. Available from: http://stats.unctad.org/FDI/TableViewer/ tableView.aspx?ReportId=334.

Vadlamannati, K.C., 2007. Explaining the affects of internal state conflict on attractiveness, value, pace, quality, opportunity cost and volatility of FDI - evidence from Sri Lanka. Funded project No. 40185001, Center for Study of Civil War (CSCW), PRIO, Oslo, Norway.

Vadlamannati, K.C., 2008. Exploring the relationship between military spending and income inequality in South Asia. Working paper No. 911, William Davidson Institute at Michigan University.

Vadlamannati, K.C. and Tamazian, A., 2006. Impact of civil war on FDI in Sri Lanka. Working Paper 2006/03, USC, Spain.

Weyland, K., 1998. The political fate of market reform in Latin America, Africa, and Eastern Europe. International studies quarterly, 42 (4), 645-674.

Wheeler, D. and Mody, A., 1992. International investment location decisions: the case of U.S. firms, Journal of international economics, 33 (1-2), 57-76.

Williams, R.L., 2000. A note on robust variance estimation for cluster-correlated data. Biometrics, 56 (2), 645-646.

World Development Indicators, 2006. World bank [online]. Available from: http://ddp-ext. worldbank.org/WDI. 


\section{Appendices}

Appendix 1. Countries under study.

\begin{tabular}{llll}
\hline Bangladesh & China & Hong Kong & India \\
Indonesia & Japan & Korea, South & Myanmar \\
Malaysia & Pakistan & Papua Geneva & Philippines \\
Sri Lanka & Singapore & Taiwan & Thailand \\
Vietnam & & & \\
\hline
\end{tabular}

Appendix 2. Data sources.

\begin{tabular}{ll}
\hline Indicators & \\
\hline Unionized labour & www.PRSgroup.com \\
Strikes and lockouts & www.PRSgroup.com \\
Literacy rates & www.PRSgroup.com \\
Infant deaths & www.PRSgroup.com \\
Capital account convertibility & Authors' own constructed dummies \\
Track record of government & Calculated from: http://ddp-ext.worldbank.org/WDI \\
Economic crisis & Authors' own constructed dummies \\
Civil liberties & www.freedomhouse.com \\
Political regime & http://www.cidcm.umd.edu/inscr/polity/ \\
Political instability & Authors' own constructed dummies \\
Conflicts & Authors' own constructed dummies \\
Levels of corruption & http://www.transparency.org/policy_research/surveys_indices/cpi \\
PMERI & Authors' own constructed index \\
Labour effectiveness I & Authors' own constructed indicator \\
Labour efficiency I & Authors' own constructed indicator \\
Labour effectiveness II & Authors' own constructed indicator \\
Labour efficiency II & Authors' own constructed indicator \\
\hline
\end{tabular}

